OPEN ACCESS

Edited by:

Falko Steinbach,

University of Surrey, United Kingdom

Reviewed by:

John C. Schwartz,

The Pirbright Institute, United Kingdom

Sabine Hammer,

University of Veterinary Medicine

Vienna, Austria

*Correspondence:

Marek Sinkora

marek@biomed.cas.cz

Specialty section:

This article was submitted to Comparative Immunology, a section of the journal

Frontiers in Immunology

Received: 26 November 2021

Accepted: 24 January 2022

Published: 11 February 2022

Citation:

Sinkora M, Stepanova K, Butler JE, Sinkora M Jr, Sinkora S and Sinkorova J (2022) Comparative Aspects of Immunoglobulin Gene Rearrangement Arrays in Different Species.

Front. Immunol. 13:823145. doi: 10.3389/fimmu.2022.823145

\section{Comparative Aspects of Immunoglobulin Gene Rearrangement Arrays in Different Species}

\author{
Marek Sinkora ${ }^{1 *}$, Katerina Stepanova ${ }^{1}$, John E. Butler ${ }^{2}$, Marek Sinkora Jr. ${ }^{1}$, \\ Simon Sinkora ${ }^{1}$ and Jana Sinkorova ${ }^{1}$ \\ ${ }^{1}$ Laboratory of Gnotobiology, Institute of Microbiology of the Czech Academy of Sciences, Novy Hradek, Czechia, \\ ${ }^{2}$ Department of Microbiology, University of lowa, lowa City, IA, United States
}

Studies in humans and mice indicate the critical role of the surrogate light chain in the selection of the productive immunoglobulin repertoire during B cell development. However, subsequent studies using mutant mice have also demonstrated that alternative pathways are allowed. Our recent investigation has shown that some species, such as pig, physiologically use preferential rearrangement of authentic light chains, and become independent of surrogate light chains. Here we summarize the findings from swine and compare them with results in other species. In both groups, allelic and isotypic exclusions remain intact, so the different processes do not alter the paradigm of B-cell monospecificity. Both groups also retained some other essential processes, such as segregated and sequential rearrangement of heavy and light chain loci, preferential rearrangement of light chain kappa before lambda, and functional $\kappa$-deleting element recombination. On the other hand, the respective order of heavy and light chains rearrangement may vary, and rearrangement of the light chain kappa and lambda on different chromosomes may occur independently. Studies have also confirmed that the surrogate light chain is not required for the selection of the productive repertoire of heavy chains and can be substituted by authentic light chains. These findings are important for understanding evolutional approaches, redundancy and efficiency of B-cell generation, dependencies on other regulatory factors, and strategies for constructing therapeutic antibodies in unrelated species. The results may also be important for explaining interspecies differences in the proportional use of light chains and for the understanding of divergences in rearrangement processes. Therefore, the division into two groups may not be definitive and there may be more groups of intermediate species.

Keywords: B cell development, B cell receptors, cell differentiation, immunoglobulin heavy and light chains, gene rearrangement 


\section{INTRODUCTION}

Immunoglobulin (Ig) gene rearrangement has evolved in all jawed vertebrates and involves recombination of variable $(\mathrm{V})$, diversity (D), and joining ( $\mathrm{J}$ ) gene segments at their corresponding loci (reviewed in 1). The number of VDJ segments, their organization, orientation and position within the genome, and their frequencies utilized in B cells are known in many species. This is the result of modern genomic sequencing techniques and available and durable single-cell analyzes. Surprisingly, information on the mechanism by which they rearrange in these different species is sparse. In fact, they are based only on findings in mice and to some extent in humans (2), and it is assumed to be the same at least in mammals. The reason for this is understandable, because while genome sequencing is currently a straightforward task, uncovering the mechanism usually requires inbred animals in sufficient numbers and the technology of genetic modification. However, there are some exceptions such as our studies in swine where we characterized the development of B cells during ontogeny (3-6), their development in bone marrow (7), identified different developmental stages of B cells and the order and status of their $\operatorname{IgH}$ and $\operatorname{IgL}$ rearrangements (8), analyzed redundant rearrangements in the thymus (9), analyzed the order of IgL $\kappa$ and $\operatorname{IgL} \lambda$ rearrangements during development (10), and showed the consequences of different rearrangement orders in recovered sequences (11) and $\operatorname{IgH}$ and IgL rearrangement configurations in individual peripheral B cells (12). These studies on non-transgenic and outbred animals were possible because of the organization of Ig loci and specific immunological properties. Pigs have a highly simplified IgH gene complex in which all $\mathrm{V}_{\mathrm{H}}$ genes belong to the ancestral $\mathrm{V}_{\mathrm{H}} 3$ family sharing the same leader and framework sequences, and only one $\mathrm{J}_{\mathrm{H}}$ segment is functional $(8,13,14)$. Porcine IgL loci are also restricted to only two $\mathrm{V}_{\mathrm{L}}$ families and only two functional $\mathrm{J}_{\mathrm{L}}$ genes for both $\operatorname{IgL\kappa }$ and $\operatorname{IgL} \lambda(8,15-18)$. Moreover, pigs possess an epitheliochorial placenta that prevents the prenatal transfer of maternal Ig (as well as smaller proteins) to the fetus $(19,20)$. This type of placentation, combined with prolonged gestation and numerous offspring, provides a favorable opportunity to characterize successive developmental steps during fetal life under naive conditions and without influence of extrinsic factors (4). In addition, pigs are precocial and do not require their mothers for survival. Late fetuses can be born aseptically into sterile isolators to easily produce germ-free piglets $(18,21,22)$. Such germ-free animals are devoid of effector, memory, and plasma B cells, including long-lived bone marrow plasma cells that could interfere with developmental studies of naive $B$ cells $(5,8,12,23,24)$. Here we summarize our findings and compare them with results from other species to show that alternative pathways of $\mathrm{V}(\mathrm{D}) \mathrm{J}$ rearrangement are used.

\section{REVIEW}

\section{Mouse Paradigm of V(D)J Rearrangement}

A model of $\mathrm{B}$ cell development and generation of $\mathrm{B}$ cell receptor (BCR) repertoire by $\mathrm{V}(\mathrm{D}) \mathrm{J}$ rearrangement is derived from mouse studies (reviewed in 1,25). This sophisticated paradigm describes the rearrangement as a tightly sequential process regulated by a surrogate light chain (SLC) composed of $\lambda 5$ (CD179b) and VpreB (CD179a). For overview of the process see Figure 1, left part. The first wave of the rearrangement occurs in the IgH locus of proB cells by the combinatorial joining of $\mathrm{D}_{\mathrm{H}}$ to $\mathrm{J}_{\mathrm{H}}$ segments on both chromosomes. The resulting preB-I cells subsequently rearrange a particular $\mathrm{V}_{\mathrm{H}}$ segment to one incomplete $\mathrm{DJ}_{\mathrm{H}}$ rearrangement on the first chromosome. Complete $\mathrm{VDJ}_{\mathrm{H}}$ rearrangement for $\mathrm{IgH}$ is tested in preB-II cells for its productivity by the ability to form preBCR by association with pre-existing SLC (reviewed in 26). If $\operatorname{IgH}$ rearrangement is productive and can associate with invariant SLC, the resulting preBCR are anchored into the plasmatic membrane and associated with the signaling components CD79a and CD79b. This membrane complex delivers stop signals for further IgH rearrangement ensuring the selection for productive rearrangement and allelic exclusion (27). If IgH rearrangement is not productive and/or fails to fold correctly with SLC, the cell has one more chance to rearrange $\mathrm{V}_{\mathrm{H}}$ to $\mathrm{DJ}_{\mathrm{H}}$ using the second chromosome. The large preB-II cells die in case of failure but survive, expand, and consecutively become small preB-II cells in case of success. Up to this stage of development, no IgL rearrangement takes place. IgL locus is rearranged only if productive IgH was successfully tested by SLC and the IgH loci are closed for further rearrangement.

IgL rearrangement thereafter begins in surviving small preBII cells initially with $\operatorname{IgL} \kappa$, which continues to rearrange until it is productive and forms an authentic BCR (28). Multiple IgLא rearrangements (editing) are possible because IgL genes, unlike the IgH locus, do not contain a $\mathrm{D}$ segment and do not lose recombination signal sequences between unused $\mathrm{V}_{\mathrm{L}}$ and $\mathrm{J}_{\mathrm{L}}$ segments. Rearrangement in the IgL $\kappa$ loci is finished when (1) any $\operatorname{IgL} \kappa$ protein can form an authentic BCR with existing IgH and small preB-II cells become immature B cells or (2) all

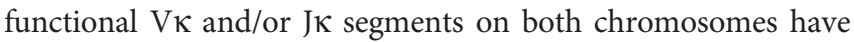
been used and/or IgL $\kappa$ loci have been inactivated. Inactivation of IgLK occurs by excision of $\mathrm{C} \kappa$ segments from the genome by recombination of any remaining $\mathrm{V} \kappa$ segment or upstream $\mathrm{C \kappa}$ recombining element ( $\mathrm{RE}$ ) to downstream recombining sequence in mice or $\kappa$ deleting element in other species (hereafter referred to as $\mathrm{KDE}$ recombination) $(28,29$; reviewed in 30). The existence of KDE has been demonstrated in all species studied, and the ablation of $\mathrm{C} \kappa$ segments by $\mathrm{V} \kappa-\mathrm{KDE}$ and RE$\mathrm{KDE}$ recombination before any $\operatorname{IgL} \lambda$ rearrangement is thought to ensure the isotypic exclusion (30).

\section{Swine Deviations From Mouse Paradigm}

Porcine B cell development begins with IgL rearrangement in the absence of IgH rearrangement or components of SLC (VpreB and $\lambda 5)(8,12)$. For overview of the process see Figure 1, right part. Similar to mice, IgLK rearrangement is a beginning, but it occurs only on the first chromosome and the precursors become $\operatorname{IgL} \kappa^{+} \operatorname{IgL} \lambda^{-} \operatorname{IgH}{ }^{-}$. There are no $\operatorname{IgH}$ rearrangements in these precursors yet, and if some occur rarely, if they are productive, and if they match productive IgL, the precursors become immature B cells expressing BCR. This is only a small fraction of the final $\operatorname{IgL\kappa }^{+} \mathrm{B}$ cell pool as evidenced by cultivation and 


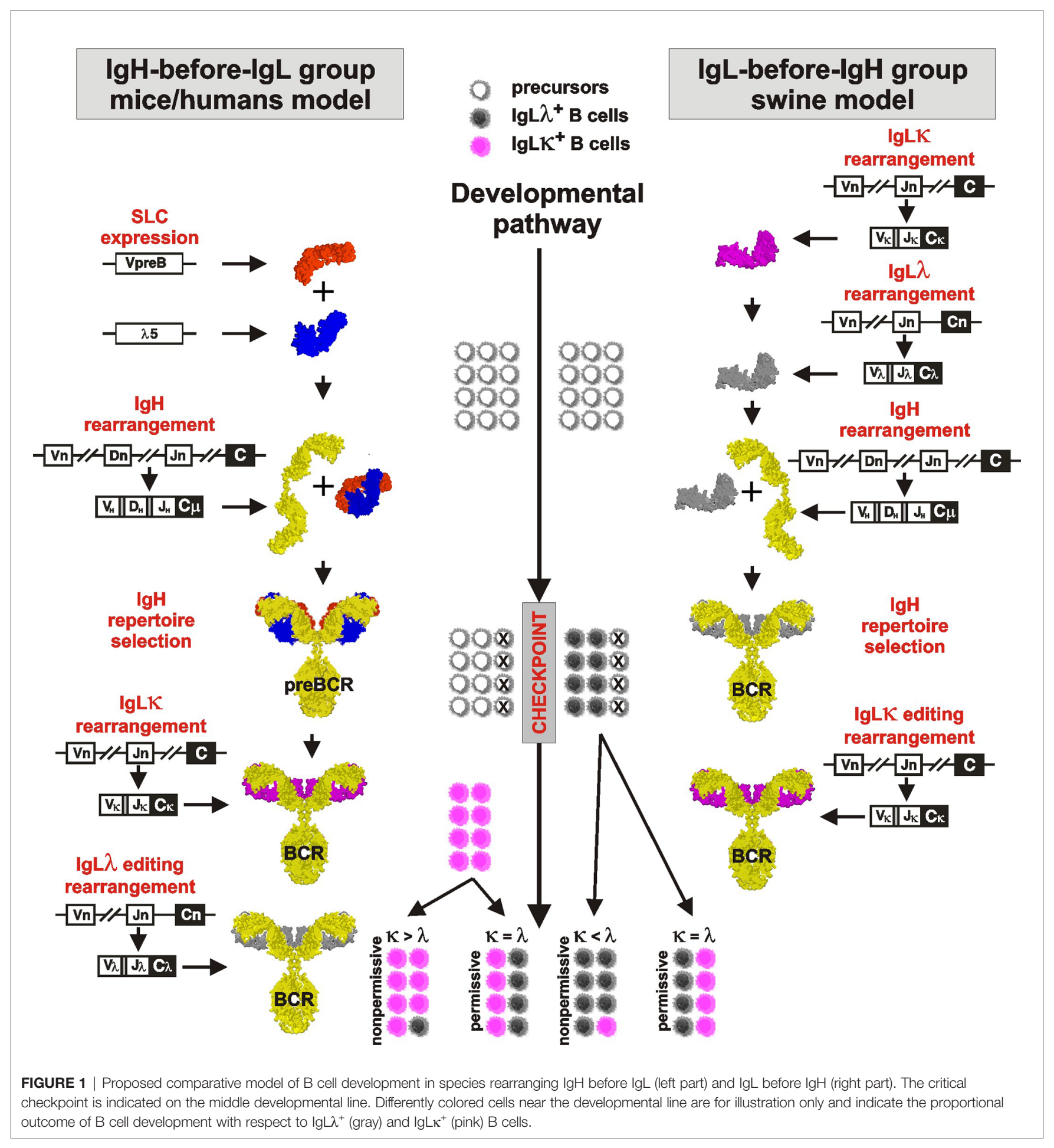

sorting studies (10). In the absence of IgH, the vast majority of the remaining cells rapidly replace the initial IgL $\kappa$ rearrangement with successive $\operatorname{IgL} \lambda$ rearrangement. These precursors thus develop from $\operatorname{IgL\kappa }^{+} \operatorname{IgL} \lambda+\operatorname{IgH}^{-}$to $\operatorname{IgL\kappa } \kappa^{-} \operatorname{IgL} \lambda+\operatorname{IgH}^{-}$ precursors, which continue to rearrange (and consume) further $\mathrm{V} \lambda$ genes until $\mathrm{IgH}$ rearrangement occurs. As indicated by sorting and sequencing studies (11), most of the initial IgLK genes are inactivated by KDE recombination. Rearrangement of IgH occurs at the next developmental stage and follows the same rules as known from mice: Incomplete $\mathrm{DJ}_{\mathrm{H}}$ rearrangements are primarily formed on both chromosomes followed by complete $\mathrm{VDJ}_{\mathrm{H}}$ on the first chromosome $(7,9)$. The IgH product is tested for its productivity and ability for surface expression by pairing with pre-existing authentic $\operatorname{IgL} \lambda$. In case that both $\operatorname{IgH}$ and $\operatorname{IgL} \lambda$ 
rearrangements are productive, the cells become immature $\operatorname{IgL} \lambda^{+}$ $B$ cells. The probability of productive $\operatorname{Ig} L \lambda$ is very high because early rearrangements are direct VJ joins (31-33). The probability of productive IgH rearrangement follows the $1 / 3$ success rule due to shifted reading frames $(3,7,9)$. In the case of defective $\operatorname{IgH}$, there is one more chance to rearrange $\mathrm{V}_{\mathrm{H}}$ to $\mathrm{DJ}_{\mathrm{H}}$ using the second chromosome. If successful, these early immature $\mathrm{B}$ cells survive and expand (8). Since initial IgLK rearrangement was replaced by successive $\operatorname{IgL} \lambda$ rearrangement before $\mathrm{IgH}$ rearrangement, the early immature $\mathrm{B}$ cells are almost exclusively $\operatorname{IgL} \lambda^{+}$. This is substantially different from mice, in which IgL $\kappa^{+}$B cells are generated earlier (28). The generation of $\operatorname{IgLK}^{+} \mathrm{B}$ cells in porcine bone marrow occurs during the transition to late immature $B$ cells by rearrangement of germline IgLK genes on the second chromosome (10). During this process, which gives rise to the majority of immature $\operatorname{IgL} \kappa^{+} \mathrm{B}$ cells, the existing IgL $\lambda$ rearrangement is silenced but remains in the $\operatorname{IgLK}^{+} \mathrm{B}$ cells. This is another principal difference from mice because the vast majority of $\operatorname{IgL\kappa }^{+} \mathrm{B}$ cells carry silenced and mostly productive $\operatorname{IgL} \lambda$ transcripts $(10,11)$. This peculiarity can be traced even in peripheral mature B cells (12). There may even be additional IgL editing in a small fraction of late immature cells if the second wave of $\operatorname{IgL} \kappa$ rearrangement is replaced by secondary $\operatorname{IgL} \lambda$ rearrangement. In this case, the existing secondary IgL $\kappa$ rearrangement is again inactivated by $\mathrm{KDE}$ recombination to allow secondary $\operatorname{IgL} \lambda$ rearrangement (10-12).

\section{What Is Essential and What Optional}

Studies in pigs have shown that some steps in the sequential process of $\mathrm{V}(\mathrm{D}) \mathrm{J}$ rearrangement are essential, whereas others are optional. The first essential process is that the $\operatorname{IgH}$ and IgL loci rearrange at different developmental stages. Thus, the process is sequential, but the respective order may vary (see below). This may be related to a reduction in the number of $\operatorname{IgL}$ isotypes during evolution, resulting in only one or two isotypes in birds and mammals. These can be more comfortably controlled than in skates and sharks, which have multiple $\operatorname{IgH}$ and IgL loci rearranged simultaneously $(34,35)$. In any case, once $\operatorname{IgH}$ rearrangement begins, it occurs consecutively on the first chromosome and, if not productive, also on the second chromosome, otherwise the developing B cell dies. Our analyses of single cells have never revealed two productive $\operatorname{IgH}$ rearrangements $(9,10)$. Furthermore, the developmental stage at which IgH rearrangements occur is also a crucial checkpoint of differentiation regulated by intrinsic factors of the bone marrow (7) always followed by several rounds of proliferation to increase a cohort of precursor B cells with identical IgH chain (reviewed in 36). Another essential step is also a preferential rearrangement of IgL $\kappa$ before IgL $\lambda$. This has been demonstrated in many other species (37) and the positions/organizations of $\kappa$-enhancers are highly conserved (30). The function of $\mathrm{KDE}$ recombination is also critical. Inhibition of IgL $\kappa$ by $\mathrm{C} \kappa$ excision occurs before the switch to $\operatorname{IgL} \lambda$ rearrangement.

On the other hand, an optional process includes the independence of $\operatorname{IgH}$ and $\operatorname{IgL}$ gene rearrangements so that the respective order may vary. While $\operatorname{IgH}$ precedes IgL rearrangement in mice, $\operatorname{IgL}$ precedes $\operatorname{IgH}$ rearrangement in swine. Interestingly, the independence of $\operatorname{IgH}$ and $\operatorname{IgL}$ rearrangement was predicted based on results with virustransformed preB cells (38) and demonstrated in IgH deficient mice, which rearrange $\operatorname{IgL}$ at normal frequencies and with normal kinetics $(39,40)$. It has also been demonstrated that a small fraction of developing B cells can rearrange IgL before IgH even in mice under physiological conditions (41). Swine can do this regularly under physiological conditions $(8,10)$. It should be emphasized that there may also be an intermediate group of animals that rearrange IgH and IgL competitively. An example of this is birds that do it very early in fetal life (42-44). Another optional process is the independence of $\operatorname{IgL} \kappa$ and $\operatorname{IgL} \lambda$ rearrangements on different chromosomes. Although IgL $\kappa$ rearrange preferentially as explained above, and both IgL $\kappa$ loci are consumed before any $\operatorname{IgL} \lambda$ rearrangement in mice, $\operatorname{IgL} \kappa$ and $\operatorname{IgL} \lambda$ rearrangements on different chromosomes may occur at different developmental stages in pigs. As also demonstrated in swine, IgL editing can occur much later in immature B cells, which is also true for any other species because BCR editing is used in the establishment of central tolerance in late immature $B$ cells (36). The other optional process is the use of SLC to select productive IgH rearrangements. Pigs use an authentic IgL and do not need SLC.

Certainly, there are still some unresolved issues, such as whether incomplete $\mathrm{DJ}_{\mathrm{H}}$ rearrangements on both chromosomes occur in the earliest precursors in all species. In swine, they do as in mice and humans $(7,8)$. We have also never observed multiple $\mathrm{D}_{\mathrm{H}}$ rearrangements in our sequences. However, $\mathrm{V}_{\mathrm{H}}$ to $\mathrm{D}_{\mathrm{H}}$ rearrangement may precede $\mathrm{D}_{\mathrm{H}}$ to $\mathrm{J}_{\mathrm{H}}$ rearrangement in rabbits (45). In chickens, multiple $\mathrm{D}_{\mathrm{H}}$ to $\mathrm{DJ}_{\mathrm{H}}$ rearrangements have been reported before a subsequent rearrangement to the $\mathrm{V}_{\mathrm{H}}$ gene (46).

It needs to be emphasized that it is not the intention of this report to discuss the molecular mechanisms of the $V(D) J$ rearrangement machinery. It is apparent that essential components are also critical enzymes, such as the recombinase-activating genes (RAG), which are required for DNA cleavage, or the terminal deoxynucleotidyl transferase ( TdT), which can facilitate $\mathrm{N}$-nucleotide additions. As indicated by genome sequencing, this is also true for recombination signal sequences (RSS) and regulatory factors required for rearrangement processes. The encyclopedic information on these aspects can be found in other reviews.

\section{Controversial Function of SLC}

Originally, SLC was expected to ensure the allelic exclusion. This was disproved by the construction of knockout mice in which different components of SLC were deleted but the exclusions remained intact $(47,48)$. Only targeted disruption of the membrane exon of $\operatorname{IgH}$ genes results in allelic inclusion (27, $49,50)$, confirming that anchoring of $\operatorname{IgH}$ in the cell membrane is essential. Experiments with transgenic mice have also demonstrated that SLC is not even required for the selection of productive IgH. The deficiency in SLC does not prevent the initiation of IgL rearrangement or the development of mature B cells $(47,48)$. Although mice lacking SLC have somehow reduced number of peripheral B cells, they have normal serum IgM levels (47) and immune responses (48). All these experiments suggest 
that the SLC play only a role in increased efficiency of B cell generation and faster membrane deposition of successfully rearranged $\operatorname{IgH}$ in the absence of IgL. The SLC is not necessary if $\operatorname{IgL}$ is already present, which happens in all $\mathrm{B}$ cells with both $\mathrm{IgH}$ and IgL successfully rearranged. Since IgH and IgL rearrangements are independent (38-41), the SLC is not necessary if the order of $\operatorname{IgH}$ and IgL rearrangement is reversed.

There are three VpreB in mice (VpreB1, VpreB2, VpreB3) and two in humans (VpreB1 and VpreB3). While VpreB1 and VpreB2 are co-expressed and serve for IgH selection (1), the role of VpreB3 is different and probably interacts with $\mathrm{IgH}$ in the endoplasmatic reticulum $(26,51)$. However, recent studies in several species indicate that the VpreB and $\lambda 5$ genes may function in other processes than the formation and testing of IgH. In chickens, no homologues of $\lambda 5$ have been identified and the function of VpreB3 in these animals is the retention of free IgL inside of cells (51). Cows have all three VpreBs but VpreB2 and VpreB3 have biological functions unrelated to B cells development (52). Marsupials have only maintained VpreB3 and do not have VpreB1, VpreB2, or $\lambda 5$ in the genome (53). Pigs have VpreB1, VpreB3, and $\lambda 5$ in the genome (10) but these are not used for $\operatorname{IgH}$ selection $(8,10)$ and they are mainly expressed in non-lymphoid cells $(8,10,33,54)$. It is therefore possible that VpreB probes the fitness of other molecules as well, and that its usage in mice for the selection of productive $\operatorname{IgH}$ rearrangements is a highly specialized role adopted by only some species.

\section{Expression of IgL on the Cell Surface Without IgH}

Initial IgL rearrangements in the absence of $\operatorname{IgH}$ can be expressed on the cell surface of early precursors in swine $(8,10)$. This is a striking observation, as it is generally assumed that $\operatorname{IgL}$ cannot anchor to the cell membrane without IgH. However, free IgL are common in human pathogenesis, and these so-called Bence Jones proteins have been known for $>170$ years (55). This demonstrates that IgL are able to escape from the endoplasmatic reticulum without being chaperoned by $\mathrm{IgH}$. Free IgL in humans are mostly a product of plasma cells in which $\operatorname{IgL}$ are produced in excess to $\operatorname{IgH}(56)$. This is understandable because humans use $\operatorname{IgH}$ before $\operatorname{IgL}$ rearrangement and the IgL produced are likely to be in excess only in plasma cells. On the other hand, mice do not produce Bence Jones proteins under normal conditions, indicating a different kind of regulation for IgL synthesis. Early porcine precursors do not have $\operatorname{IgH}$, so IgL is present in excess until $\mathrm{IgH}$ rearrangement occurs. Unfortunately, the mechanism by which free IgL attaches to the surface is not fully known. The vast majority of studies investigate the secreted free IgL. However, surface expression of free IgL has been demonstrated in virustransformed preB cells, which also showed that free IgL do not associate with other proteins (38). More sophisticated studies showed that free IgL associates with the outer membrane via interaction with phospholipids such as sphingomyelin A (57). Importantly, free IgL are only associated with the surface of cells that produce these IgL (57). Our results also exclude the possibility that free $\operatorname{IgL}$ on a surface may be acquired incidentally from other sources (8).

\section{The Role of KDE, IgL Isotypic Exclusion and Distribution of IgL Rearrangements in B Cells}

Preferential usage of IgL $\kappa$ rearrangements on both chromosomes in mice (37) and the mechanism of IgL $\kappa$ inhibition by KDE recombination prior to any $\operatorname{IgL} \lambda$ rearrangements (30) have four important consequences: (1) $\operatorname{IgL}^{+} \mathrm{B}$ cells are generated earlier, (2) $\operatorname{IgL\kappa }^{+} B$ cells highly predominate over $\operatorname{IgL} \lambda^{+} B$ cells, (3) $\operatorname{IgL} \kappa^{+}$ $B$ cells have both IgL $\lambda$ loci in the germline, while (4) $\operatorname{IgL} \lambda^{+} B$ cells have rearranged $\operatorname{IgL} \kappa$ loci inactivated by $\mathrm{C} \kappa$ ablation $(28,58)$.

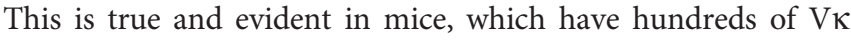

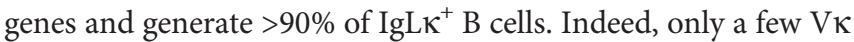
and $\mathrm{J} \kappa$ genes are required for productive IgL $\kappa$ rearrangement because the $1 / 3$ chance for out-of-frame rearrangement can be overcome by about three successive rearrangements and only on one chromosome. However, the proportional usage of IgLK and $\operatorname{IgL} \lambda$ genes is not the same in all species, and some use $>90 \% \operatorname{IgL} \lambda$ (see below and Table 1), which is not easily explained by preferential IgL $\kappa$ rearrangement and KDE recombination.

In any case, $\mathrm{KDE}$ recombination (leading to $\mathrm{C} \kappa$ ablation and inhibition of IgL $\kappa$ genes before IgL $\lambda$ rearrangement) appears to be an effective mechanism to achieve isotypic exclusion. Such an exclusion function would be of particular interest given that KDE recombination is highly conserved in many (if not all) species (30). On the other hand, studies in humans showed the coexpression of multiple $\operatorname{IgL} \kappa$ and $\operatorname{IgL} \lambda$ rearrangements in different combinations in single B cells (65). Studies in mice showed that IgL $\kappa$ production does not inhibit secondary rearrangements and multiple productive IgL can be detected in single cells (66). Studies in pigs extended these findings from the perspective of species which use IgL before IgH rearrangement and confirmed that multiple and even productive $\operatorname{IgL} \lambda$ rearrangements are present in $\operatorname{IgLK}^{+}$B cells $(8,10-12)$. Moreover, multiple IgL rearrangements can be effectively transcribed in a single cell $(12,65)$. Also, not all $\mathrm{IgL \kappa}^{+} \mathrm{B}$ cells undergo $\mathrm{C} \kappa$ deletion by $\mathrm{KDE}$ recombination on the first chromosome before rearranging on the second $(10,66)$. The coexistence of multiple productive IgL rearrangements in a single cell is highlighted in fish (67), where KDE cannot control up to four different IgL types encoded by distinct $C_{L}$ genes $(18,34)$. Therefore, the function of KDE in isotypic exclusion is implausible. More probably, KDE recombination supports efficient switching from $\operatorname{IgL} \kappa$ to $\operatorname{IgL} \lambda$ rearrangement, but has no control over which IgL allele is rearranged, whether it is productive, transcribed, and expressed. Our sorting data suggest that unused IgL rearrangements are silenced in translation or in export of $\operatorname{IgL}$ protein because they have the corresponding mRNA but are not expressed on the surface (10). Silencing of the IgH locus is partially known (68) and is ensured by nonsense-mediated decay (NMD) (69). Whether a similar mechanism operates for IgL is unknown, namely because different IgL are located on different chromosomes and can be silenced even when they are productive. Some reports indicate that silencing operates after 
TABLE 1 | Number of biologically functional (and total) gene segments in different species*.

\begin{tabular}{|c|c|c|c|c|c|c|c|c|c|}
\hline Species & VK IGKV & JK IGKJ & V $\lambda$ IGLV & J $\lambda$ IGLJ & $\mathbf{V}_{\mathrm{H}}$ IGHV & $D_{H}$ IGHD & $\mathbf{J}_{\mathbf{H}}$ IGHJ & IgLא usage & SLC (VpreB/ $/ \lambda 5)$ \\
\hline \multirow[t]{2}{*}{ Mice } & 80 & 4 & 2 & 4 & $>100$ & 16 & 3 & $95 \%$ & YES, B cell genesis \\
\hline & $(>100)$ & (5) & (2) & (4) & $(>100)$ & (31) & (4) & & \\
\hline \multirow[t]{2}{*}{ Rats } & $>100$ & 5 & 8 & 2 & $>100$ & 25 & 4 & $90 \%$ & $?$ \\
\hline & $(>100)$ & (6) & (10) & (3) & $(>100)$ & (35) & (4) & & \\
\hline \multirow[t]{2}{*}{ Humans } & 44 & 5 & 32 & 4 & 45 & 27 & 6 & $60 \%$ & YES, B cell genesis \\
\hline & $(>100)$ & (5) & $(>100)$ & (6) & $(130)$ & (30) & (9) & & \\
\hline \multirow[t]{2}{*}{ Pigs } & 10 & 2 & 10 & 2 & 10 & 2 & 1 & $50 \%$ & YES, other processes \\
\hline & (14) & (5) & (23) & (4) & (25) & (4) & (5) & & \\
\hline \multirow[t]{2}{*}{ Goats } & 6 & 1 & 25 & 1 & 4 & 2 & 1 & $20 \%$ & $?$ \\
\hline & (15) & (4) & (63) & $(2)$ & (34) & (4) & (6) & & \\
\hline \multirow[t]{2}{*}{ Horses } & 19 & 4 & 27 & 4 & 4 & 35 & 8 & $7 \%$ & $?$ \\
\hline & (60) & (5) & (144) & (6) & (50) & $(40)$ & (8) & & \\
\hline \multirow[t]{2}{*}{ Sheep } & 8 & 1-NC? ${ }^{\#}$ & 14 & 1 & 6 & 4 & 2 & $5 \%$ & $?$ \\
\hline & (13) & (3) & (43) & (2) & (10) & $(2)$ & (6) & & \\
\hline \multirow[t]{2}{*}{ Cattle } & 6 & $1-N^{\#}$ & 24 & 5 & 10 & 9 & 2 & $5 \%$ & YES, B genesis?, other processes \\
\hline & (25) & (4) & (63) & (8) & (36) & (23) & (4) & & \\
\hline \multirow[t]{2}{*}{ Marsupials } & 37 & 2 & 35 & 8 & 21 & $3 ?$ & 2 & $35 \%$ & $\mathrm{NO}$, other processes \\
\hline & (122) & (2) & (64) & (8) & (25) & (3) & (6) & & \\
\hline \multirow[t]{2}{*}{ Chickens (birds)? } & 0 & 0 & $1^{\$}$ & 1 & $1^{\$}$ & 16 & 1 & $0 \%$ & $\mathrm{NO}$, other processes \\
\hline & & & $(200)$ & (1) & $(100)$ & (16) & (1) & & \\
\hline \multirow[t]{2}{*}{ Bats } & 0 & 0 & 93 & 7 & 66 & 8 & 7 & $0 \%$ & $\mathrm{NO}$, other processes \\
\hline & & & $(>100)$ & (80) & $(77)$ & (8) & (9) & & \\
\hline
\end{tabular}

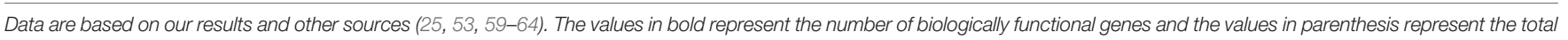
number of genes.

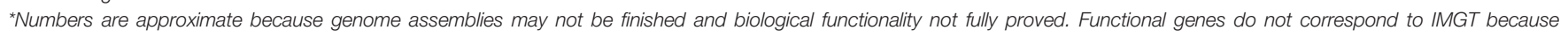
functionality in IMGT is based on sequences and mostly not tested for expression.

${ }^{\#} N C$ means that putatively functional genes have noncanonical RSS so that rearrangement is highly inefficient or impossible.

$\$$ Chickens use gene conversion and pseudogenes can be used in functional rearrangements.

?Unknown or uncertain.

translation on a "best-fit, best-serve" basis when transcription and translation of unused IgL is at a very low level. This would be consistent with findings in mice (66).

It must be emphasized that the final $\mathrm{KDE}$ recombination depends on the available number of J $\kappa$ rather than $V \kappa$ genes, since the number of possible successive rearrangements is limited by the smaller number. If a given species has only one functional $\mathrm{J} \kappa$, the further editing is only KDE-mediated CK ablation. This is not at all uncommon as Table 1 shows. Goats, sheep, and cattle have only one functional J $\kappa$ among several other nonfunctional ones (59). Furthermore, the remaining J $\kappa$ in cattle and sheep has a noncanonical RSS (59) that may favor immediate KDE-mediated ablation because initial functional rearrangement is inefficient or impossible. This could lead to the elimination of almost all IgL $\kappa$ rearrangements and be only the final step before the evolutionary loss of all IgLK usage, as occurred in bats $(60,61)$.

\section{Can Authentic IgL Be Used for Selection of Productive IgH Repertoire?}

SLC is invariant and therefore always "productive". It can theoretically bind to any productive $\operatorname{IgH}$ rearrangement to ensure its selection. This appears as a huge advantage over authentic $\operatorname{IgL}$ because the initial $\operatorname{IgL}$ rearrangements in precursors may be out of frame or nonproductive for other reasons, such as internal stop codons. However, investigation in mice has shown that as many as $50-70 \%$ of productive $\mathrm{IgH}$ fail to pair with SLC and developing cells become apoptotic (48; reviewed in 1). On the other hand, experiments in pigs have shown that the initial IgL rearrangements used for selection of subsequent $\mathrm{IgH}$ rearrangements are $>88 \%$ in-frame, have no mutations, and no $\mathrm{N}$-additions (11). Such success rate for authentic IgL is considerably higher than has been reported experimentally for SLC. Authentic IgL use also different $\mathrm{V}_{\mathrm{L}}$ and $\mathrm{J}_{\mathrm{L}}$ genes and could allow the generation of $\mathrm{B}$ cells whose $\operatorname{IgH}$ would not be capable of pairing with always the same but always imperfect SLC (48). Therefore, the IgH repertoire selected by authentic IgL should not be biased by the existence of one type of non-polymorphic peptide chains like SLC, but selection is driven by a germline authentic IgL. In fact, each type of IgL with its specific sequence could serve as a different type of SLC, so selection driven by authentic $\operatorname{IgL}$ could have a substantial advantage over SLC, and apoptic turnover could be even lower. Repeated experiments have shown that in the absence of antigenic pressure (under fetal and germ-free conditions), both $\operatorname{IgL} \kappa$ and $\operatorname{IgL} \lambda$ rearrangements are direct IGLV-IGLJ joins without deletions and $\mathrm{N}$ additions $(32,33)$.

\section{Efficiency of B Cell Generation and Evolution of Ig Rearrangement}

Based on current knowledge, it is difficult to estimate whether the use of authentic IgL is less redundant and more efficient than SLCdependent selection (see section above). The established order of $\operatorname{IgH}$ before $\operatorname{IgL}$ gene rearrangement seems to be the most ancestral because this strategy is used in amphibians (70). However, amphibians and fish do not use SLC and the number of B cells per gram of body mass is $>10$-fold lower than in birds or 
mammals $(70,71)$. A similar effect is seen in marsupials, which also keep IgH before IgL rearrangements and lack SLC (53). These mammals have minimal levels of serum antibodies even several months after birth (72), which is comparable to the kinetics of mice with genetically deficient SLC (48). Thus, one group of successor animals could increase the efficiency of B cell generation by employing the existing components of SLC. Others might reverse the order of IgH and IgL rearrangement and omit the SLC requirement or employ yet other mechanisms such as the gene conversion in chickens (44). The reason why some species do not retain the ancestral $\operatorname{IgH}$ before IgL rearrangement may be due to their limited $\operatorname{IgH}$ repertoire (62). Chickens have only a single functional $\mathrm{V}_{\mathrm{H}}$ and $\mathrm{J}_{\mathrm{H}}$ segment (44) and pigs are restricted to ten closely related $\mathrm{V}_{\mathrm{H}}$ and one $\mathrm{J}_{\mathrm{H}}$ segment (reviewed in 18, 22). Although it has been demonstrated that CDR3 junctional diversity can compensate for the limited combinatorial repertoire $(13,18)$, limited or highly homologous $\mathrm{V}_{\mathrm{H}}$ genes can also be a limiting factor when invariant SLC does not associate with them (48). This may also be a reason why species with limited $\mathrm{V}_{\mathrm{H}}$ repertoire have a much higher number of $\mathrm{V}_{\mathrm{L}}$ segments in the genome (61).

The explanation for the different efficiency of $\mathrm{B}$ cell generation can be the critical checkpoint at a developmental stage where $\operatorname{IgH}$ rearrangements occur. This checkpoint has been characterized in mice (73; reviewed in 36), humans (37), and also in swine (7). In mice and humans, the checkpoint is overcome by expression of functional preBCR (74). The same checkpoint occurs in porcine $\mathrm{IgL}^{+}$precursors during $\mathrm{IgH}$ rearrangement and is overcome by expression of authentic $\operatorname{BCR}(7,8)$. In all species, the checkpoint is regulated by intrinsic factors of the bone marrow (or appropriate stromal cells), and it is followed by several rounds of proliferation to increase a cohort of precursor B cells with identical IgH chains. However, the generation of $\mathrm{B}$ cells without the bone marrow is still possible but very inefficient $(3,74)$, as in the case of the variants described in the above paragraph.

Two important observations were made in experiments with porcine bone marrow stromal cells: the first confirms that B cells developing in the absence of stromal cells contain the $\mathrm{IgH}$ rearrangement on only one chromosome, while stromal cells support the rearrangement on both chromosomes (7). This phenomenon was previously observed in vivo during early ontogeny, when B cells developing in the yolk sac and fetal liver prior to a functional bone marrow were rare and had only a single productive IgH rearrangement (3). Such an observation cannot be made in mice because maturation of $\mathrm{B}$ cells in the fetal liver of mice coincides with maturation in the bone marrow, while in fetal pigs there is a 25-day window in between (4). These results collectively indicate that the opening of the second chromosome for rearrangement does not occur in the absence of the bone marrow. The second observation confirms that the absence of stromal cells leads to the accumulation of $\operatorname{IgL} \lambda^{+} \operatorname{IgH}{ }^{-}$ precursors and the preferential generation of $\operatorname{IgL} \lambda^{+} \mathrm{B}$ cells (8, 10). This is also exactly what happens in vivo during early ontogeny, when $\operatorname{IgL} \lambda$ transcripts are about 20-times more frequent than $\operatorname{IgL} \kappa(54,75)$. The apparent absence of $\operatorname{IgL} \kappa$ transcripts in the yolk sac and fetal liver led us formerly to the incorrect conclusion that $\operatorname{IgL} \lambda$ might precede the rearrangement of the IgL $\kappa$ genes in pigs (54). Differences in the ability of the bone marrow to support B cell development throughout the checkpoint or its timing can therefore explain interspecies differences in the ration of $\operatorname{IgL\kappa } / \operatorname{IgL} \lambda$ usage (see below).

\section{IgLא to IgL $\lambda$ Ratio in Different Species}

As mentioned earlier, $>95 \%$ of mouse B cells are IgL $\kappa^{+}$. However, humans and pigs have about the same amount of $\operatorname{IgLK}^{+}$and $\operatorname{IgL} \lambda^{+}$, while species like cows, sheep, horses, dogs, and cats have $>90 \%$ of $\operatorname{IgL} \lambda^{+}$B cells (63). The enormous interspecies differences are often explained by the disproportionate number of $\mathrm{V} \kappa$ and $\mathrm{V} \lambda$ genes in a genome, which in some cases corresponds to the expressed $\operatorname{IgL\kappa } / \operatorname{IgL} \lambda$ ratio $(25,64)$ but in others does not (61); see Table 1 .

However, the preferential IgL $\kappa$ rearrangements on both chromosomes and the mechanism of KDE recombination do not allow the generation of substantial numbers of $\operatorname{IgL} \lambda^{+}$B cells (see above), especially in species that have relatively high numbers of functional VK genes such as horse (19), pig (10), sheep (8), cat (12) or dog (19) (Table 1; www.imgt.org). According to the results from swine, the difference in the use of $\operatorname{IgL} \kappa$ compared to $\operatorname{IgL} \lambda$ is more likely explained by the sequence of IgL rearrangements on different chromosomes and/or the permissiveness of the microenvironment to support efficient B cell development. Although IgL rearrangement begins with $\operatorname{IgL} \kappa$ and progresses to IgL $\lambda$ probably in all mammals (28, 29 ), the outcome may be the result of two different processes (1): secondary $\operatorname{IgL} \kappa$ is not consumed before $\operatorname{IgL} \lambda$ rearrangement and/or (2) secondary $\operatorname{IgL} \kappa$ rearrangement is not permitted in given developmental step. In species that use IgL before IgH rearrangement such as swine, these possibilities lead to early genesis of $\operatorname{IgL} \lambda^{+} \mathrm{B}$ cells, while most $\operatorname{IgL} \kappa^{+} \mathrm{B}$ cells are generated later and require permissive bone marrow stromal cells (10). Therefore, the dozen-fold prevalence of early $\operatorname{IgL} \lambda^{+} \mathrm{B}$ cells is compensated to approximately $1: 1$ ratio of $\operatorname{IgL} \lambda: \operatorname{IgL} \kappa$ in immature B cells (10). If the bone marrow is less permissive, the ratio may be less favorable for $\operatorname{IgLK}^{+} \mathrm{B}$ cells, and if it is not permissive, the majority of all B cells would be $\operatorname{IgL} \lambda^{+}$. This could be the case in some $\operatorname{IgL} \lambda$-high species, in which the lymphoid potential of the bone marrow declines with age (52). The same phenomenon can be observed artificially in transgenic mice that have a longer time for successive IgL rearrangement, resulting in a considerable shift for higher usage of $\operatorname{IgL} \lambda$ over $\operatorname{IgL\kappa }(76)$. In species that use IgH before IgL rearrangement, such as humans, the same possibilities may lead to the protracted or suspended second wave of $\operatorname{IgL} \kappa$ rearrangement or accelerated $\operatorname{IgL} \lambda$ rearrangement. This can be demonstrated by analyses of IgL $\kappa$ rearrangements in $\operatorname{IgL} \lambda^{+}$B cells. Mouse $\operatorname{IgL} \lambda^{+}$B cells are generated as a last chance for developing precursors when IgL $\kappa$ loci are exhausted (66). On the other hand, a substantial number of human IgL $\lambda^{+}$B cells may have IgL $\kappa$ loci in the germline or rearranged, and only about half of them have IgL $\kappa$ genes deleted $(28,73)$. The effect of rearrangement order and the permissivity to support efficient B cell development is indicated in middle part of Figure 1. 
Additional evidence that the timing and sequence of each rearrangement control the proportional utilization of $\operatorname{IgL}$ genes comes from the proportional usage of the different $\mathrm{V}_{\mathrm{L}}$ and $\mathrm{J}_{\mathrm{L}}$ segments in different species. The majority of mouse $\operatorname{IgLK}^{+} \mathrm{B}$ cells

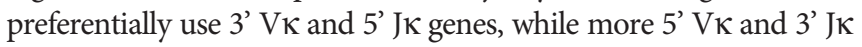
segments are used in $\operatorname{IgL} \lambda^{+} \mathrm{B}$ cells $(77,78)$ since a pre-existing $\mathrm{VJ}_{\mathrm{L}}$ can only be edited by a rearrangement that uses more $5^{\prime} \mathrm{V}_{\mathrm{L}}$ along with more 3' $\mathrm{J}_{\mathrm{L}}$ genes. However, when SLC is inactivated in transgenic mice, they use more 5 ' $\mathrm{V} \kappa$ genes (78) and resemble more swine, which also do not use SLC. The situation in mice is also different from humans, in which both naive and experienced $B$ cells preferentially use more $3^{\prime}-\mathrm{V} \kappa$ genes (79). However, more 5' V $\lambda$ genes are used than even in the naive human repertoire (80), likely reflecting a more independent $\operatorname{Ig} L \lambda$ rearrangement $(28,73)$. In any case, the situation is quite different in the pigs, which have been repeatedly reported to use more $5^{\prime} \mathrm{V}_{\mathrm{L}}$ genes in both $\operatorname{IgL\kappa }(16)$ and $\operatorname{IgL} \lambda(15,32,33,81)$. This discrepancy is mainly caused by the early use of IgL $\kappa$ rearrangement in precursor cells, which is replaced by $\operatorname{IgL} \lambda$ rearrangement before $\operatorname{IgH}$ rearrangement (11). The depletion and inhibition of porcine $\mathrm{C} \kappa$ genes on the first chromosome during this early development has another fundamental limitation: only IgLK genes on the second chromosome can be used to generate

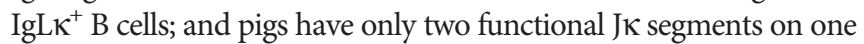
allele (18). Such restriction to only two consecutive $\operatorname{IgL\kappa }$ rearrangements is probably the reason why only two major $\mathrm{V} \kappa$ genes are preferentially used in swine $(11,32)$ and why the $V \kappa$ repertoire is severely restricted compared to $\mathrm{V} \lambda(32,33)$. Higher flexibility and diversity of IgL $\lambda$ than of IgL $\kappa$ has also been found in other $\lambda$-high species (61). All these findings indicate that the disproportionate number of $\mathrm{V} \kappa$ and $V \lambda$ genes in different species is not the cause of differential $V \kappa$ and $V \lambda$ usage, but the effect of different rearrangement order and/or developmental dynamics.

Another important factor is the limited number of $\mathrm{V}_{\mathrm{L}}$ and/or $\mathrm{J}_{\mathrm{L}}$ gene segments, which approaches zero. If species can rely on one type of IgL, the second may gradually goes unused or be eliminated. This is the case in birds, which have been able to do so probably because they use gene conversion (42-44), but also in bats, which have expanded the $V \lambda$ and $V_{H}$ repertoire (60). These are two known species that have eliminated IgLK (Table 1). The opposite might be a case in mice, which use $95 \%$ of IgLK and limited the number of $\mathrm{V} \lambda$ genes to only two or three (28). Indeed, mice are very specific in the IgL $\lambda$ locus and use two tandem $\operatorname{V} \lambda \mathrm{J} \lambda \mathrm{C} \lambda$ cassettes (58) instead of multiple $\mathrm{V} \lambda$ genes arrayed upstream of $\mathrm{J} \lambda \mathrm{C} \lambda$ cassettes as known from other species (21). In any case, ungulates are also interesting as described earlier. In general, these species have sufficient numbers of putative $\mathrm{J} \kappa$ and $\mathrm{J} \lambda$ segments, but many of them are mutated and not useful for functional rearrangements. As a result, sheep and cattle have almost no functional JK genes. They are either mutated in the $\mathrm{W}(\mathrm{F}) \mathrm{GxG}$ motif and therefore nonfunctional or have noncanonical RSS, making rearrangement inefficient or impossible (59). In comparison, goats have one $\mathrm{J} \kappa$ segment that is still fully functional, and this may be a reason why they have more $\operatorname{IgL} \lambda^{+}$ $B$ cells than sheep and cattle (59). In this respect, sheep and cattle, followed by goats, might just be other species that follow the bats in the complete loss of $\operatorname{IgLK}^{+} \mathrm{B}$ cells. It is surprising that many thriving species are able to keep the number of functional $\mathrm{V}(\mathrm{D}) \mathrm{J}$ segments to a minimum. This is especially true for $\operatorname{IgH}$, which is critical for BCR formation. For example, pigs have all five $\mathrm{J}_{\mathrm{H}}$ segments "functional" in terms of the WGxG motif and the absence of stop codons (14). However, three of the five have noncanonical RSS (14), and functional experiments have shown that only one of the remaining can be used for functional rearrangement (82). A similar situation appears to apply to goats (59).

\section{Conclusion}

In summary, different species appear to have evolved different strategies for the order of rearrangement of Ig genes and for the selection of a productive Ig repertoire. Possibilities for these strategies have even been indicated in mice themselves, which showed that the order of rearrangement is independent $(27,40$, 41 ) and SLC is unnecessary $(47,48)$. Apparently, all these species have survived with comparable success. On the other hand, differential regulation of rearrangement order and mechanisms of repertoire selection may have evolutionary and practical consequences. In the IgL-before-IgH group, extensive editing of the $\operatorname{IgL} \lambda$ repertoire occurs very early and before $\operatorname{IgH}$ rearrangement. On the other hand, $\operatorname{IgL} \lambda$ repertoire is edited in the IgH-before-IgL group only when IgL $\kappa$ is unsuccessful. These principles could lead to higher diversification of $\operatorname{IgL} \lambda$ loci in the IgL-before-IgH group, while higher diversification of $\operatorname{IgL\kappa }$ loci in the $\operatorname{IgH}$-before-IgL group. Another consequence of the enormous differences between species is the possibility of choosing the uncomplicated experimental systems for practical purposes. All porcine $\mathrm{V}_{\mathrm{H}}$ genes share the same leader and framework sequences and only one $\mathrm{J}_{\mathrm{H}}$ segment is functional. Furthermore, both porcine $\operatorname{IgL\kappa }$ and $\operatorname{IgL} \lambda$ loci contain only two families and two functional $\mathrm{J}_{\mathrm{L}}$ genes. This allows the recovery of all $\mathrm{VDJ}_{\mathrm{H}}$ rearrangements using a single nondegenerate primer set or the generation of deficient pigs for B cells by modifying just a single $\mathrm{J}_{\mathrm{H}}$ segment (82). However, it must always be considered if the regulatory components of Ig rearrangement also need to be copied into the genome. The production of B-celldeficient pigs may be a simple task, but it may be difficult to generate genetically modified pigs that produce a sufficient amount of human antibodies.

\section{AUTHOR CONTRIBUTIONS}

All authors listed have made a substantial, direct, and intellectual contribution to the work, and approved it for publication.

\section{FUNDING}

The research was supported by the Czech Science Foundation grants No. 19-01504S and No. 20-03282S.

\section{ACKNOWLEDGMENTS}

We would like to gratefully acknowledge Nancy Wertz (University of Iowa, Iowa City, IA) for discussions and critical reading of the manuscript. 


\section{REFERENCES}

1. Melchers F. Checkpoints That Control B Cell Development. J Clin Invest (2015) 4:1-8. doi: 10.1172/JCI78083

2. Klein F, Feldhahn N, Mooster JL, Sprangers M, Hofmann WK, Wernet P, et al. Tracing the Pre-B to Immature B Cell Transition in Human Leukemia Cells Reveals a Coordinated Sequence of Primary and Secondary IGK Gene Rearrangement, IGK Deletion, and IGL Gene Rearrangement. J Immunol (2005) 174:367-75. doi: 10.4049/jimmunol.174.1.367

3. Sinkora M, Sun J, Sinkorova J, Christenson RK, Ford SP, Butler JE. Antibody Repertoire Development in Fetal and Neonatal Piglets. VI. B Cell Lymphogenesis Occurs at Multiple Sites With Differences in the Frequency of in-Frame Rearrangements. J Immunol (2003) 170:1781-8. doi: 10.4049/ jimmunol.170.4.1781

4. Sinkora M, Butler JE. The Ontogeny of the Porcine Immune System. Dev Comp Immunol (2009) 33:273-83. doi: 10.1016/j.dci.2008.07.011

5. Sinkora M, Stepanova K, Sinkorova J. Different Anti-CD21 Antibodies can be Used to Discriminate Developmentally and Functionally Different Subsets of B Lymphocytes in Circulation of Pigs. Dev Comp Immunol (2013) 39:409-18. doi: 10.1016/j.dci.2012.10.010

6. Butler JE, Santiago-Mateo K, Sun X-Z, Wertz N, Sinkora M, Francis DH. Antibody Repertoire Development in Fetal and Neonatal Piglets. XX. B Cell Lymphogenesis is Absent in the Ileal Peyer's Patches, Their Repertoire Development is Antigen Dependent, and They are Not Required for B Cell Maintenance. J Immunol (2011) 187:5141-49. doi: 10.4049/jimmunol.1101871

7. Sinkora M, Sinkorova J. B Cell Lymphogenesis in Swine is Located in the Bone Marrow. J Immunol (2014) 193:5023-32. doi: 10.4049/jimmunol.1401152

8. Sinkora M, Sinkorova J, Stepanova K. Ig Light Chain Precedes Heavy Chain Gene Rearrangement During Development of B Cells in Swine. J Immunol (2017) 198:1543-52. doi: 10.4049/jimmunol.1601035

9. Sinkorova J, Stepanova K, Butler JE, Sinkora M. T Cells in Swine Completely Rearrange Immunoglobulin Heavy Chain Genes. Dev Comp Immunol (2019) 99:103396. doi: 10.1016/j.dci.2019.103396

10. Sinkora M, Stepanova K, Sinkorova J. Immunoglobulin Light Chain $\kappa$ Precedes $\lambda$ Rearrangement in Swine But a Majority of $\lambda^{+}$B Cells are Generated Earlier. Dev Comp Immunol (2020) 111:3751. doi: 10.1016/ j.dci.2020.103751

11. Stepanova K, Sinkorova J, Srutkova D, Sinkora MJr., Sinkora S, Splichal I, et al. The Order of Immunoglobulin Light Chain $\kappa$ and $\lambda$ Usage in Primary and Secondary Lymphoid Tissues of Germ-Free and Conventional Piglets. Dev Comp Immunol (2022).

12. Sinkora M, Stepanova K, Sinkorova J. Consequences of the Different Order of Immunoglobulin Gene Rearrangements in Swine. Dev Comp Immunol (2022) 126:104196. doi: 10.1016/j.dci.2021.104196

13. Butler JE, Weber P, Sinkora M, Sun J, Ford SJ, Christenson RK. Antibody Repertoire Development in Fetal and Neonatal Piglets. II. Characterization of Heavy Chain Complementarity-Determining Region 3 Diversity in the Developing Fetus. J Immunol (2000) 165:6999-7010. doi: 10.4049/jimmunol.165.12.6999

14. Eguchi-Ogawa T, Wertz N, Sun XZ, Piumi F, Uenishi H, Wells K, et al. Antibody Repertoire Development in Fetal and Neonatal Piglets. XI. The Relationship of Variable Heavy Chain Gene Usage and the Genomic Organization of the Variable Heavy Chain Locus. J Immunol (2010) 184:3734-42. doi: 10.4049/jimmunol.0903616

15. Schwartz JC, Lefranc MP, Murtaugh MP. Organization, Complexity and Allelic Diversity of the Porcine (Sus Scrofa Domestica) Immunoglobulin Lambda Locus. Immunogenetics (2012) 64:399-407. doi: 10.1007/s00251-011-0594-9

16. Schwartz JC, Lefranc MP, Murtaugh MP. Evolution of the Porcine (Sus Scrofa Domestica) Immunoglobulin Kappa Locus Through Germline Gene Conversion. Immunogenetics (2012) 64:303-11. doi: 10.1007/s00251-011-0589-6

17. Sinkora M, Butler JE, Lager KM, Potockova H, Sinkorova J. The Comparative Profile of Lymphoid Cells and the T and B Cell Spectratype of Germ-Free Piglets Infected With Viruses SIV, PRRSV or PCV2. Vet Res (2014) 45:91. doi: 10.1186/s13567-014-0091-x

18. Butler JE, Wertz N, Sinkora M. Antibody Repertoire Development in Swine. Annu Rev Anim Biosci (2017) 5:255-79. doi: 10.1146/annurev-animal022516-022818

19. Sinkora M, Sun J, Butler JE. Antibody Repertoire Development in Fetal and Neonatal Piglets. V. VDJ Gene Chimeras Resembling Gene Conversion
Products are Generated at High Frequency by PCR In Vitro. Mol Immuno (2000) 37:1025-34. doi: 10.1016/S0161-5890(01)00022-0

20. Butler JE, Sinkora M, Wertz N, Holtmeier W, Lemke CD. Development of the Neonatal B and T Cell Repertoire in Swine: Implications for Comparative and Veterinary Immunology. Vet Res (2006) 37:417-41. doi: 10.1051/ vetres:2006009

21. Butler JE, Zhao Y, Sinkora M, Wertz N, Kacskovics I. Immunoglobulins, Antibody Repertoire and B Cell Development. Dev Comp Immunol (2009) 33:321-33. doi: 10.1016/j.dci.2008.06.015

22. Sinkora M, Butler JE. Progress in the Use of Swine in Developmental Immunology of B and T Lymphocytes. Dev Comp Immunol (2016) 58:1-17. doi: 10.1016/j.dci.2015.12.003

23. Butler JE, Sun J, Wertz N, Sinkora M. Antibody Repertoire Development in Swine. Dev Comp Immunol (2006) 30:199-221. doi: 10.1016/j.dci.2005.06.025

24. Sinkora M, Sinkorova J, Cimburek Z, Holtmeier W. Two Groups of Porcine $\mathrm{Tcr} \gamma \delta^{+}$Thymocytes Behave and Diverge Differently. J Immunol (2007) 178:711-19. doi: 10.4049/jimmunol.178.2.711

25. Collins AM, Watson CT. Immunoglobulin Light Chain Gene Rearrangements, Receptor Editing and the Development of a Self-Tolerant Antibody Repertoire. Front Immunol (2018) 9:2249. doi: 10.3389/ fimmu.2018.02249

26. Martensson IL, Keenan RA, Licence S. The Pre-B-Cell Receptor. Curr Opin Immunol (2007) 19:137-42. doi: 10.1016/j.coi.2007.02.006

27. Kitamura D, Rajewsky K. Targeted Disruption of Mu Chain Membrane Exon Causes Loss of Heavy-Chain Allelic Exclusion. Nature (1992) 356:154-56. doi: $10.1038 / 356154 \mathrm{a} 0$

28. van der Burg M, Tumkaya T, Boerma M, de Bruin-Versteeg S, Langerak AW, van Dongen JJ. Ordered Recombination of Immunoglobulin Light Chain Genes Occurs at the IGK Locus But Seems Less Strict at the IGL Locus. Blood (2001) 97:1001-8. doi: 10.1182/blood.V97.4.1001

29. Korsmeyer SJ, Hieter PA, Sharrow SO, Goldman CK, Leder P, Waldmann TA. Normal Human B Cells Display Ordered Light Chain Gene Rearrangements and Deletions. J Exp Med (1982) 156:975-85. doi: 10.1084/jem.156.4.975

30. Das S, Nikolaidis N, Nei M. Genomic Organization and Evolution of Immunoglobulin Kappa Gene Enhancers and Kappa Deleting Element in Mammals. Mol Immunol (2009) 46:3171-77. doi: 10.1016/j.molimm.2009.05.180

31. Stepanova K, Sinkora M. The Expression of CD25, CD11b, SWC1, SWC7, MHC-II, and Family of CD45 Molecules can be Used to Characterize Different Stages of Gamma Delta T Lymphocytes in Pigs. Dev Comp Immunol (2012) 36:728-40. doi: 10.1016/j.dci.2011.11.003

32. Butler JE, Wertz N, Sun X. Antibody Repertoire Development in Fetal and Neonatal Piglets. XIV. Highly Restricted IGKV Gene Usage Parallels the Pattern Seen With IGLV and IGHV. Mol Immunol (2013) 55:329-36. doi: 10.1016/j.molimm.2013.03.011

33. Wertz N, Vazquez J, Wells K, Sun J, Butler JE. Antibody Repertoire Development in Fetal and Neonatal Piglets. XII. Three IGLV Genes Comprise $70 \%$ of the Pre-Immune Repertoire and There is Little Junctional Diversity. Mol Immunol (2013) 55:319-28. doi: 10.1016/j.molimm.2013.03.012

34. Criscitiello MF, Flajnik MF. Four Primordial Immunoglobulin Light Chain Isotypes, Including Lambda and Kappa, Identified in the Most Primitive Living Jawed Vertebrates. Eur J Immunol (2007) 37:2683-94. doi: 10.1002/ eji.200737263

35. Hsu E. V(D)J Recombination: Of Mice and Sharks. Adv Exp Med Biol (2009) 650:166-79. doi: 10.1007/978-1-4419-0296-2_14

36. Nemazee D. Receptor Editing in Lymphocyte Development and Central Tolerance. Nat Rev Immunol (2006) 6:728-40. doi: 10.1038/nri1939

37. Hardy RR, Hayakawa K. B Cell Development Pathways. Annu Rev Immunol (2001) 19:595-621. doi: 10.1146/annurev.immunol.19.1.595

38. Kubagawa H, Cooper MD, Carroll AJ, Burrows PD. Light-Chain Gene Expression Before Heavy-Chain Gene Rearrangement in Pre-B Cells Transformed by Epstein-Barr Virus. Proc Natl Acad Sci USA (1989) 86:2356-60. doi: 10.1073/pnas.86.7.2356

39. Grawunder U, Haasner D, Melchers F, Rolink A. Rearrangement and Expression of $\kappa$ Light Chain Genes can Occur Without $\mu$ Heavy Chain Expression During Differentiation of Pre-B Cells. Int Immunol (1993) 5:160918. doi: 10.1093/intimm/5.12.1609

40. Ehlich A, Schaal S, Gu H, Kitamura D, Muller W, Rajewsky K. Immunoglobulin Heavy and Light Chain Genes Rearrange Independently 
at Early Stages of B Cell Development. Cell (1993) 72:695-704. doi: 10.1016/ 0092-8674(93)90398-A

41. Novobrantseva TI, Martin VM, Pelanda R, Muller W, Rajewsky K, Ehlich A. Rearrangement and Expression of Immunoglobulin Light Chain Genes can Precede Heavy Chain Expression During Normal B Cell Development in Mice. J Exp Med (1999) 189:75-88. doi: 10.1084/jem.189.1.75

42. Benatar T, Tkalec L, Ratcliffe MJ. Stochastic Rearrangement of Immunoglobulin Variable-Region Genes in Chicken B-Cell Development. Proc Natl Acad Sci USA (1992) 89:7615-9. doi: 10.1073/pnas.89.16.7615

43. Reynaud CA, Bertocci B, Dahan A, Weill JC. Formation of the Chicken B-Cell Repertoire: Ontogenesis, Regulation of Ig Gene Rearrangement, and Diversification by Gene Conversion. Adv Immunol (1994) 57:353-578. doi: 10.1016/S0065-2776(08)60676-8

44. Ratcliffe MJ. Antibodies, Immunoglobulin Genes and the Bursa of Fabricius in Chicken B Cell Development. Dev Comp Immunol (2006) 30:101-18. doi: 10.1016/j.dci.2005.06.018

45. Jasper PJ, Zhai SK, Kalis SL, Kingzette M, Knight KL. B Lymphocyte Development in Rabbit: Progenitor B Cells and Waning of B Lymphopoiesis. J Immunol (2003) 171:6372-80. doi: 10.4049/ jimmunol.171.12.6372

46. Reynaud CA, Anquez V, Weill JC. The Chicken D Locus and its Contribution to the Immunoglobulin Heavy Chain Repertoire. Eur J Immunol (1991) 11:2661-70. doi: 10.1002/eji.1830211104

47. Shimizu T, Mundt C, Licence S, Melchers F, Martensson IL. Vpreb1/Vpreb2/ $\lambda 5$ Triple-Deficient Mice Show Impaired B Cell Development But Functional Allelic Exclusion of the IgH Locus. J Immunol (2002) 168:6286-93. doi: 10.4049/jimmunol.168.12.6286

48. ten Boekel E, Melchers F, Rolink A. Changes in the VH Gene Repertoire of Developing Precursor B Lymphocytes in Mouse Bone Marrow Mediated by the Pre-B Cell Receptor. Immunity (1997) 7:357-68. doi: 10.1016/S1074-7613 (00)80357-X

49. Kitamura D, Roes J, Kühn R, Rajewsky K. A B Cell-Deficient Mouse by Targeted Disruption of the Membrane Exon of the Immunoglobulin $\mathrm{Mu}$ Chain Gene. Nature (1991) 350:423-26. doi: 10.1038/350423a0

50. Shaffer AL, Schlissel MS. A Truncated Heavy Chain Protein Relieves the Requirement for Surrogate Light Chains in Early B Cell Development. J Immunol (1997) 159:1265-75.

51. Rosnet O, Blanco-Betancourt C, Grivel K, Richter K, Schiff C. Binding of Free Immunoglobulin Light Chains to VpreB3 Inhibits Their Maturation and Secretion in Chicken B Cells. J Biol Chem (2004) 279:10228-36. doi: 10.1074/ jbc.M312169-A200

52. Ekman A, Ilves M, Iivanainen A. B Lymphopoiesis is Characterized by Pre-B Cell Marker Gene Expression in Fetal Cattle and Declines in Adults. Dev Comp Immunol (2012) 37:39-49. doi: 10.1016/j.dci.2011.12.009

53. Wang X, Parra ZE, Miller RD. A VpreB3 Homologue in a Marsupial, the Gray Short-Tailed Opossum, Monodelphis Domestica. Immunogenetics (2012) 64:647-52. doi: 10.1007/s00251-012-0626-0

54. Sun X, Wertz N, Lager K, Sinkora M, Stepanova K, Tobin G, et al. Antibody Repertoire Development in Fetal and Neonatal Piglets. XXII. $\lambda$ Rearrangement Precedes $\kappa$ Rearrangement During B-Cell Lymphogenesis in Swine. Immunology (2012) 137:149-59. doi: 10.1111/j.1365-2567.2012.03615.x

55. Jones HBIII. On a New Substance Occurring in the Urine of a Patient With Mollities Ossium. Phil Trans R Soc (1848) 138:55-62. doi: 10.1098/ rstl.1848.0003

56. Hopper JE, Papagiannes E. Evidence by Radioimmunoassay That MitogenActivated Human Blood Mononuclear Cells Secrete Significant Amounts of Light Chain Ig Unassociated With Heavy Chain. Cell Immunol (1986) 101:122-31. doi: 10.1016/0008-8749(86)90191-7

57. Hutchinson AT, Ramsland PA, Jones DR, Agostino M, Lund ME, Jennings CV, et al. Free Ig Light Chains Interact With Sphingomyelin and are Found on the Surface of Myeloma Plasma Cells in an Aggregated Form. J Immunol (2010) 185:4179-88. doi: 10.4049/jimmunol.1001956

58. Nadel B, Cazenave PA, Sanchez P. Murine Lambda Gene Rearrangements: The Stochastic Model Prevails Over the Ordered Model. EMBO J (1990) 9:435-40. doi: 10.1002/j.1460-2075.1990.tb08128.x

59. Schwartz JC, Philp RL, Bickhart DM, Smith TPL, Hammond JA. The Antibody Loci of the Domestic Goat (Capra Hircus). Immunogenetics (2018) 70:317-26. doi: 10.1007/s00251-017-1033-3
60. Larson PA, Bartlett ML, Garcia K, Chitty J, Balkema-Buschmann A, Towner J, et al. Genomic Features of Humoral Immunity Support Tolerance Model in Egyptian Rousette Bats. Cell Rep (2021) 35:109140. doi: 10.1016/j.celrep.2021.109140

61. Sun Y, Liu Z, Ren L, Wei Z, Wang P, Li N, et al. Immunoglobulin Genes and Diversity: What We Have Learned From Domestic Animals. J Anim Sci Biotechnol (2012) . 3:18. doi: 10.1186/2049-1891-3-18

62. Sitnikova T, Su C. Coevolution of Immunoglobulin Heavy- and Light-Chain Variable-Region Gene Families. Mol Biol Evol (1998) 15:617-25. doi: 10.1093/ oxfordjournals.molbev.a025965

63. Butler JE. Immunoglobulin Diversity, B-Cell and Antibody Repertoire Development in Large Farm Animals. Rev Sci Tech (1998) 17:43-70. doi: 10.20506/rst.17.1.1096

64. Ford JE, Home WA, Gibson DM. Light Chain Isotype Regulation in the Horse. Characterization of Ig Kappa Genes. J Immunol (1994) 153:1099-111.

65. Shi Z, Zhang Q, Yan H, Yang Y, Wang P, Zhang Y, et al. More Than One Antibody of Individual B Cells Revealed by Single-Cell Immune Profiling. Cell Discovery (2019) 5:64. doi: 10.1038/s41421-019-0137-3

66. Yamagami T, ten Boekel E, Andersson J, Rolink A, Melchers F. Frequencies of Multiple IgL Chain Gene Rearrangements in Single Normal or kappaL ChainDeficient B Lineage Cells. Immunity (1999) 11:317-27. doi: 10.1016/S10747613(00)80107-7

67. Perdiguero P, Morel E, Díaz-Rosales P, Tafalla C. Individual B Cells Transcribe Multiple Rearranged Immunoglobulin Light Chains in Teleost Fish. iScience (2021) 24:102615. doi: 10.1016/j.isci.2021.102615

68. Eberle AB, Herrmann K, Jäck HM, Mühlemann O. Equal Transcription Rates of Productively and Nonproductively Rearranged Immunoglobulin Mu Heavy Chain Alleles in a Pro-B Cell Line. RNA (2009) 15:1021-28. doi: 10.1261/rna.1516409

69. Li S, Wilkinson MF. Nonsense Surveillance in Lymphocytes? Immunity (1998) 8:135-41. doi: 10.1016/S1074-7613(00)80466-5

70. Du Pasquier L, Robert J, Courtet M, Mussmann R. B-Cell Development in the Amphibian Xenopus. Immunol Rev (2000) 175:201-13. doi: 10.1111/j.1600065x.2000.imr017501.x

71. Pettinello R, Dooley H. The Immunoglobulins of Cold-Blooded Vertebrates. Biomolecules (2014) 4:1045-69. doi: 10.3390/biom4041045

72. Fehrenkamp BD, Morrissey KA, Miller RD. Opossum Milk IgG is From Maternal Circulation and Timing of Transfer Correlates With Neonatal Immune Development. Reprod Fertil Dev (2019) 31:1246-51. doi: 10.1071/RD18121

73. Ghia P, ten Boekel E, Sanz E, de la Hera A, Rolink A, Melchers F. Ordering of Human Bone Marrow B Lymphocyte Precursors by Single-Cell Polymerase Chain Reaction Analyses of the Rearrangement Status of the Immunoglobulin $\mathrm{H}$ and $\mathrm{L}$ Chain Gene Loci. J Exp Med (1996) 184:2217-29. doi: 10.1084/jem.184.6.2217

74. Rolink AG, Winkler T, Melchers F, Andersson J. Precursor B Cell ReceptorDependent B Cell Proliferation and Differentiation Does Not Require the Bone Marrow or Fetal Liver Environment. J Exp Med (2000) 191:23-32. doi: 10.1084/jem.191.1.23

75. Butler JE, Wertz N, Sun J, Wang H, Lemke C, Chardon P, et al. The PreImmune Variable Kappa Repertoire of Swine is Selectively Generated From Certain Subfamilies of Vkappa2 and One Jkappa Gene. Vet Immunol Immunopathol (2005) 108:127-37. doi: 10.1016/j.vetimm.2005.07.016

76. Rolink A, Grawunder U, Haasner D, Strasser A, Melchers F. Immature Surface $\mathrm{Ig}^{+} \mathrm{B}$ Cells can Continue to Rearrange $\kappa$ and $\lambda \mathrm{L}$ Chain Gene Loci. J Exp Med (1993) 178:1263-70. doi: 10.1084/jem.178.4.1263

77. Kaushik A, Schulze DH, Bona C, Kelsoe G. Murine V Kappa Gene Expression Does Not Follow the VH Paradigm. J Exp Med (1989) 169:1859-64. doi: $10.1084 /$ jem.169.5.1859

78. Sun L, Kono N, Shimizu T, Toh H, Xue H, Numata O, et al. Distorted Antibody Repertoire Developed in the Absence of Pre-B Cell Receptor Formation. Biochem Biophys Res Commun (2018) 495:1411-17. doi: 10.1016/j.bbrc.2017.11.171

79. Girchick HJ, Lipsky PE. The Kappa Gene Repertoire of Human Neonatal B Cells. Mol Immunol (2001) 38:1113-27. doi: 10.1016/S0161-5890(02)00039-1

80. Richl P, Stern U, Lipsky PE, Girschick HJ. The Lambda Gene Immunoglobulin Repertoire of Human Neonatal B Cells. Mol Immunol (2008) 45:320-27. doi: 10.1016/j.molimm.2007.06.155

81. Guo N, Su M, Xie Z, Wang K, Yuan H, Li M, et al. Characterization and Comparative Analysis of Immunoglobulin Lambda Chain Diversity in a Neonatal Porcine Model. Vet Immunol Immunopathol (2018) 195:84-91. doi: 10.1016/j.vetimm.2017.12.002 
82. Mendicino M, Ramsoondar J, Phelps C, Vaught S, Ball T, LeRoith J, et al. Generation of Antibody- and B Cell-Deficient Pigs by Targeted Disruption of the J-Region Gene Segment of the Heavy Chain Locus. Transgenic Res (2011) 20:625-41. doi: 10.1007/s11248-010-9444-z

Conflict of Interest: The authors declare that the research was conducted in the absence of any commercial or financial relationships that could be construed as a potential conflict of interest.

Publisher's Note: All claims expressed in this article are solely those of the authors and do not necessarily represent those of their affiliated organizations, or those of the publisher, the editors and the reviewers. Any product that may be evaluated in this article, or claim that may be made by its manufacturer, is not guaranteed or endorsed by the publisher.

Copyright $\odot 2022$ Sinkora, Stepanova, Butler, Sinkora, Sinkora and Sinkorova. This is an open-access article distributed under the terms of the Creative Commons Attribution License (CC BY). The use, distribution or reproduction in other forums is permitted, provided the original author(s) and the copyright owner(s) are credited and that the original publication in this journal is cited, in accordance with accepted academic practice. No use, distribution or reproduction is permitted which does not comply with these terms. 